\title{
Suppressive Effects of Welsh Onion Extracts on Mucus Hyper-Production in Human Airway Cells
}

\author{
AkikoTakashima $^{1^{*}}$, KimihikoSano ${ }^{1}$, Jun Iwashita ${ }^{2}$, Keishi Hata ${ }^{3}$ \\ ${ }^{1}$ Sano Inc., 3-4-2 Oroshi-machi, Akita, 010-0061, Japan \\ ${ }^{2}$ Faculty of Bioresource Sciences, Akita Prefectural University, Shimoshinjo Nakano, Akita 010-0195, Japan \\ ${ }^{3}$ Akita Research Institute of Food \& Brewing, 4-26 Sanuki, Arayamachi, Akita 010-1623, Japan
}

*Corresponding author: Akiko Takashima, Sano Inc., 3-4-2 Oroshi-machi, Akita, 010-0061, Japan, Tel: +81-18-862-6644; Fax: +81-18-862-6646; E-mail: a-takashima@sano-co.com

\begin{abstract}
We investigated the suppressive effects of Welsh onion (Allium fistulosum $L$.) on the hyper-production of mucins in NCI-H292 human lung cancer cells. Periodic acid-Schiff staining showed that the $50 \%(\mathrm{v} / \mathrm{v})$ ethanol extract of Welsh onion suppressed mucus glycoprotein production in cells, whereas the water and ethanol extracts did not. A real-time RT-PCR analysis demonstrated that the 50\% ethanol extract attenuated the gene expression of MUC2 and MUC5AC, which are major airway mucus components, in NCI-H292 cells stimulated with lipopolysaccharide (LPS). Furthermore, dot blot hybridization revealed that the extract at $100 \mu \mathrm{g} / \mathrm{ml}$ attenuated the hyper-production of the MUC5AC protein in LPS-stimulated NCI-H292 cells.
\end{abstract}

\author{
Received Date: Sept 6, 2016 \\ Accepted Date: Sept 12, 2016 \\ Published Date: Sept 17, 2016
}

Citation: Takashima, A., et al. Suppressive Effects of Welsh Onion Extracts on Mucus Hyper-Production in Human Airway Cells. (2016) Lett Health Biol Sci 1(2): 34- 36

DOI: $10.15436 / 2475-6245.16 .011$

\section{Introduction}

Approximately 480,000 tons of Welsh onion (Allium fistulosum L.) are harvested each year in Japan. Some of the biological activities of Welsh onion such as its activation of immune responses as well as its antioxidant, anti-glycation, and anticancer effect shave been reported ${ }^{[1-3]}$. In Japan, Welsh onion is regarded as an effective treatment for colds, and the anti-influenza A activity of its fructan has been demonstrated ${ }^{[4]}$.

Mucin glycoproteins are secreted by mucosal goblet cells and mucin-encoding genes (MUC1, 2, 3, 4, 5AC, 5B, 6, $7,8,13$, and 19) are expressed in the airways and/or lungs ${ }^{[5,6]}$. These mucins are necessary for maintaining the viscosity of the mucus layer; however, the hyper-production of mucins in airways causes asthma and aspiration pneumonitis in dysphagic patients $^{[7]}$. NCI-H292 human cancer cells produce mucus glycoproteins such as MUC5AC, and the protein levels of these glycoproteins are up-regulated by cytokines and chemical substances $^{[8-10]}$. Agents for alleviating airway obstruction effectively normalize mucus production in NCI-H292 cells, and, thus, these cells have been used as an in vitro model of mucus hyper-production in airways ${ }^{[11,12]}$. We previously established an assay system for intracellular and extracellular mucin proteins in NCI-H292 cells ${ }^{[13]}$. In the present study, we examined the effects of extracts of Welsh onion on LPS-stimulated mucin hyper-production in NCI-H292 cells.

\section{Materials and Methods}

\section{Cell culture}

The human lung cancer cell line, NCI-H292 was purchased from the American Type Culture Collection. NCI-H292 cells were cultured in RPMI-1640 supplemented with $10 \%$ fetal bovine serum (FBS), 100 units $/ \mathrm{ml}$ penicillin, and $100 \mu \mathrm{g} / \mathrm{ml}$ streptomycin in a $5 \% \mathrm{CO}_{2}$ incubator.

\section{Welsh onion extracts}

The edible parts (leaf and stem) of commercially available Welsh onion $(1.0 \mathrm{~g})$ were extracted in $50 \mathrm{ml}$ of distilled water, $50 \%(\mathrm{~V} / \mathrm{V})$ ethanol and ethanol $(99.5 \%$ ethanol), and the extracts were collected by centrifugation. The water extract was dried by lyophilization and the other alcohol extracts by evaporation. The extraction procedure yielded $222.9 \mathrm{mg}$ of the water extract, and $273.1 \mathrm{mg}$ of the $50 \%$ ethanol extract, and $175.5 \mathrm{mg}$ of the ethanol extract.

\section{Cell growth assay and Periodic Acid-Schiff (PAS) staining}

NCI-H292 cells $\left(3 \times 10^{4}\right)$ were precultured in 24-well plates $(1 \mathrm{ml})$ for $12 \mathrm{~h}$, and subsequently incubated without or with $50 \mu \mathrm{g} / \mathrm{ml}$ of lipopolysaccharide (LPS, Wako Pure Chemical Industries), LPS plus $100 \mu \mathrm{g} / \mathrm{ml}$ Welsh onion extract, or LPS plus $100 \mu \mathrm{M}$ S-carboxy-methyl L-cysteine (CC, Tokyo Chemical Industry). Viable cell numbers were counted using the Trypan

Copyrights: (C) 2016 Takashima, A. This is an Open access article distributed under the terms of Creative Commons Attribution 4.0 International License. 
blue dye exclusion assay under a microscope. PAS-positive cells were visualized as follows. Cells were fixed with ethanol-acetic acid (3:1), washed with distilled water twice, and then treated with $0.5 \%$ PAS reagent followed by $0.6 \%$ sodium metabisulfite containing $0.05 \mathrm{~N} \mathrm{HCl}$.

\section{Real-time RT-PCR}

The effects of the three Welsh onion extracts on the expression of genes encoding mucins in NCI-H292 cells were examined. Cells ( $3 \times 10^{4}$ cells) were seeded and pre cultured in 24well plates $(1 \mathrm{ml})$ for $12 \mathrm{~h}$, and then incubated with or without the extracts at $100 \mu \mathrm{g} / \mathrm{ml}$ for 2 days. The isolation of total RNA and real-time RT-PCR were performed as previously described ${ }^{[14]}$. The relative expression level of each mRNA was normalized by the amount of glyceraldehyde-3-phosphate dehydrogenase (GAPDH) mRNA. The primer sequences used in the present study were 5'-GCACCGTCAAGGCTGAGAAC-3' (sense) and 5'-TGGTGAAGACGCCAGTGGA-3' (antisense) for GAPDH, 5'-CATTATTCAGAGCGAGTATGGAGCA-3' (sense) and 5'-TCTTCAGTGAACATCAGAGGTGGA-3' (antisense) for $\beta$-glucuronidase (GUS), 5'-CAACCAGCACGTCATCCTGAA-3' (sense) and 5'-GATGCAAATGCTGGCATCAAAG-3' (antisense) for MUC2, and 5'-CTGACCTGCCGACCCAAG-3' (sense) and 5'-CCCGCTCTGCTCCTGGTA-3' (antisense) for MUC5AC.

\section{MUC5AC protein assay}

NCI-H292 cells ( 1 x $10^{3}$ cells) were cultured in 96-well plates at $37^{\circ} \mathrm{C}$ for $48 \mathrm{~h}$ with or without the test samples. After extracellular proteins (culture media) had been collected, intracellular proteins were dissolved by lysis in $100 \mu$ l of Tris-buffered saline (TBS; $150 \mathrm{mM} \mathrm{NaCl}$ and $10 \mathrm{mM}$ Tris $\mathrm{pH} 7.5$ ) containing $0.1 \%$ SDS. These protein solutions $(40 \mu \mathrm{l})$ were blotted onto an Immobil on membrane (Millipore) by the Dot Blot Hybridization Manifold (SCIE-PLAS). The membrane was treated with $4 \%$ skim milk (Gibco Oriental) in $0.2 \%$ Tween 20-TBS (TBS-T) at $4^{\circ} \mathrm{C}$ for $12 \mathrm{~h}$, and then incubated with a mouse anti-human MUC5AC antibody (1:2,000 in 4\% skim milk, MS145-P1, Thermo Scientific) for $1 \mathrm{~h}$. The membrane was washed 5 times for 5 min each with TBS-T and then incubated with rabbit anti-mouse $\operatorname{IgG}(\mathrm{H}+\mathrm{L})(1: 2,000$ in 4\% skim milk, NA931V, GE Healthcare) for $1 \mathrm{~h}$. The membrane was washed 5 times, enzyme reactions were detected with a Luminata Forte western HRP substrate (WBLUF0500, Millipore) and a Chemidoc image analyzer (BioRad).

\section{Results and Discussion}

We examined the effects of Welsh onion extracts on the production of mucus glycoproteins such as MUC5AC using PAS staining and NCI-H292 cell growth. The production of mucus glycoproteins was greater in LPS-treated NIC-H292 cells than in untreated cells (Figure 1A-b).The application of $100 \mu \mathrm{M} \mathrm{CC}$, which suppresses mucus production by cells ${ }^{[10]}$, down-regulated LPS-induced glycoprotein production (Figure $1 \mathrm{~A}-\mathrm{c}$ ). The 50\% ethanol extract of Welsh onion markedly attenuated the LPS-induced hyper-production of mucus glycoproteins, and this effect appeared to be stronger than that by the water or ethanol extract (Figure 1A-d-f). Additionally, neither the $100 \mu \mathrm{g} / \mathrm{ml}$ Welsh onion extracts nor $100 \mu \mathrm{M}$ CC affected NCI-H292 cell growth (Figure 1B).

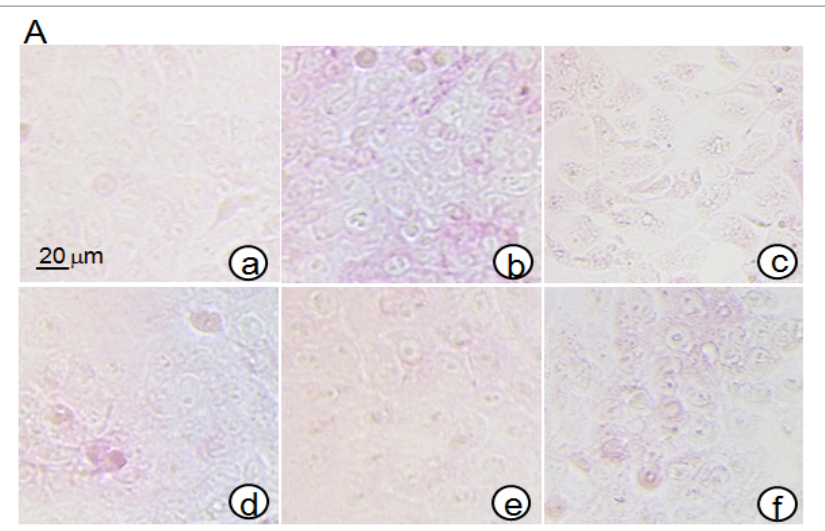

B

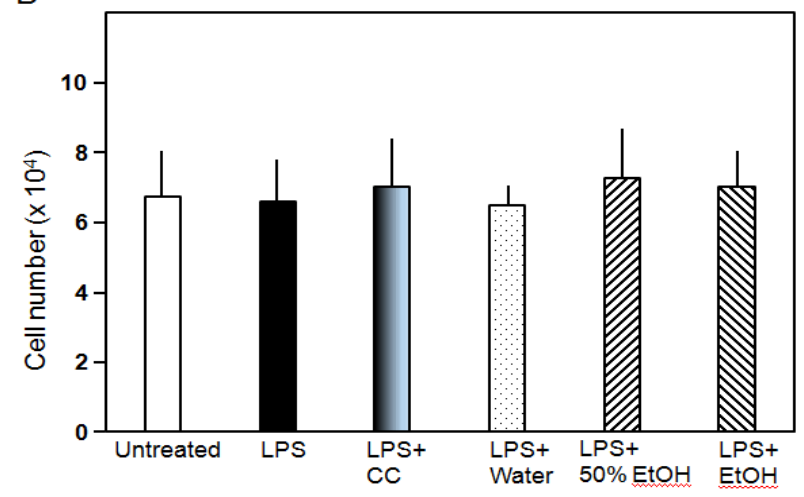

Figure 1: Effects of Welsh onion extracts on mucus glycoprotein production in and the growth of NCI-H292 cells.

A: Following the treatment without (a) or with $50 \mu \mathrm{g} / \mathrm{ml}$ LPS (b), LPS plus $100 \mu \mathrm{M}$ CC (c), LPS plus $100 \mu \mathrm{g} / \mathrm{ml}$ water extract (d), LPS plus $100 \mu \mathrm{g} / \mathrm{ml} 50 \%$ ethanol extract (e), or LPS plus ethanol extract (f) for $48 \mathrm{~h}$, mucus glycoproteins in NCI-H292 cells were visualized by PAS staining.

B: Following the treatment without $(\square)$ or with $50 \mu \mathrm{g} / \mathrm{ml}$ LPS ( $\square$, LPS plus $100 \mu \mathrm{M} \mathrm{CC}(\square)$, LPS plus $100 \mathrm{mg} / \mathrm{ml}$ water extract $(\square)$, LPS plus $100 \mathrm{mg} / \mathrm{ml} \mathrm{50 \%}$ ethanol extract $(\boldsymbol{Z})$, or LPS plus ethanol extract ( $\boldsymbol{\nabla}$ ) for $48 \mathrm{~h}$, the number of viable NCI-H292 cells was counted using the Trypan blue dye exclusion method. Data are expressed as the mean \pm standard deviation $(\mathrm{n}=3)$. The significance of differences was analyzed using a one-way ANOVA with Tukey's multiple comparison test.

Table 1: Suppressive effects of Welsh onion extract on the expression of mucin genes in LPS-treated NCI-H292 cells.

\begin{tabular}{|l|l|l|l|l|}
\hline & \multicolumn{4}{|l|}{ Relative intensity/GAPDH (fold) } \\
\hline Gene name & Untreated & LPS & LPS + CC & $\begin{array}{l}\text { LPS + Welsh } \\
\text { onion }\end{array}$ \\
\hline GUS & $1.0 \pm 0.2$ & $0.9 \pm 0.3$ & $0.9 \pm 0.7$ & $0.9 \pm 0.2$ \\
\hline MUC2 & $1.0 \pm 0.2 * *$ & $2.0 \pm 0.1$ & $2.3 \pm 0.5$ & $0.8 \pm 0.1 * *$ \\
\hline MUC5AC & $1.0 \pm 0.3^{* *}$ & $3.4 \pm 0.7$ & $0.9 \pm 0.5^{* *}$ & $0.9 \pm 0.2^{* *}$ \\
\hline
\end{tabular}

Following the treatment without or with LPS, LPS plus $100 \mu \mathrm{M} \mathrm{CC}$, or

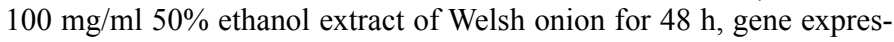
sion levels were measured by real-time RT-PCR. Data are expressed as the mean \pm standard deviation $(\mathrm{n}=3)$. The significance of differences was analyzed using a one-way ANOVA with Dunnett's multiple comparison test. ${ }^{* *} \mathrm{p}<0.01 v$ s the LPS group

Mucus glycoproteins produced by NCI-H292 cells were mainly composed of MUC2 and MUC5AC ${ }^{[15]}$. We investigated whether the $50 \%$ ethanol extract of Welsh onion suppressed the expression of these mucin genes (Table 1). Real-time RT-PCR demonstrated that the expression of the GUS gene was not influenced by any treatment used in the present study. MUC2 
and MUC 5AC gene expression levels were higher in NCI-H292 cells treated with LPS at $50 \mu \mathrm{g} / \mathrm{ml}$ than in untreated cells. In LPS-stimulated NCI-H292 cells, $100 \mu \mathrm{M} \mathrm{CC}$ markedly reduced the gene expression levels of MUC5AC, but not those of MUC2. MUC2 and MUC5AC gene expression levels were $40.0 \%$ and $26.5 \%$ lower, respectively, in cells treated with the $50 \%$ ethanol extract of Welsh onion than in LPS-stimulated cells.

Furthermore, we measured the inhibitory effects of the $50 \%$ ethanol extract on intracellular and extracellular MUC5AC protein levels in NCI-H292 cells (Figure 2). Intracellular and extracellular levels of MUC5AC were 8.9- and 8.8-fold higher, respectively, in LPS-treated cells than in untreated cells. The $50 \%$ ethanol extract of Welsh onion markedly decreased LPS-induced MUC5AC hyper-production by cells, similar to the CC treatment, and reduced LPS-induced increases in MUC5AC levels by 2.2- (intracellular) and 3.0-fold (extracellular).
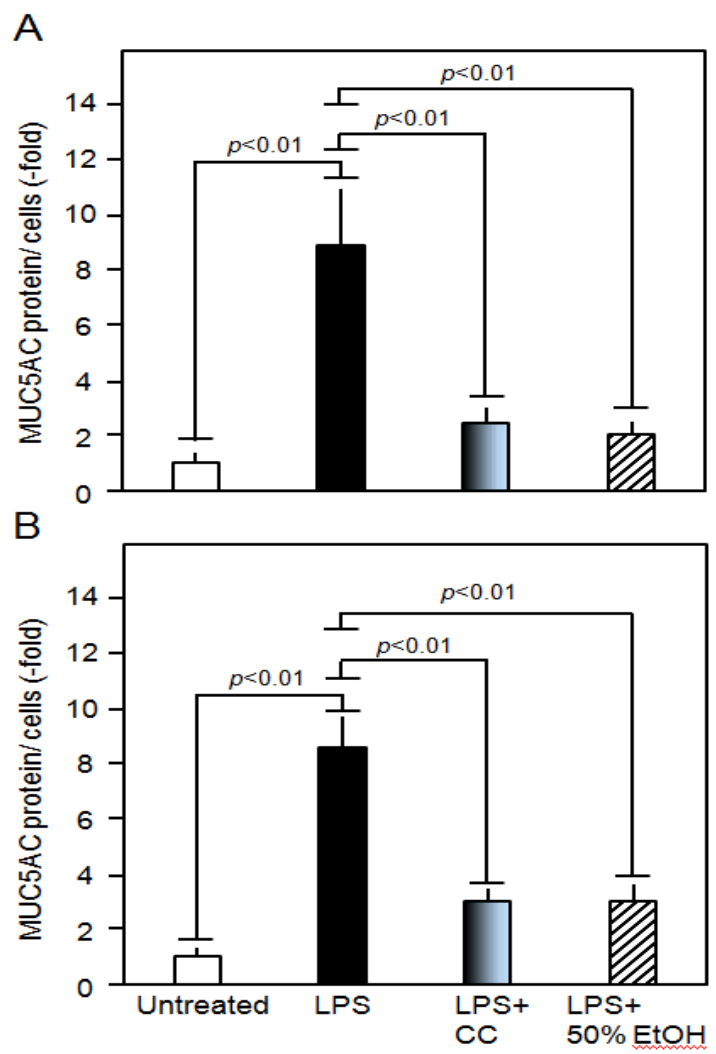

Figure 2: Intra- and extracellular MUC5AC protein levels in NCI-H292 cells.

Following the treatment without $(\square)$ or with $50 \mu \mathrm{g} / \mathrm{ml}$ LPS ( $\boldsymbol{\square}$, LPS plus $100 \mu \mathrm{M}$ CC $(\boldsymbol{\square})$, or LPS plus $100 \mu \mathrm{g} / \mathrm{ml} 50 \%$ ethanol extract ( $\boldsymbol{Z}$ ) for $48 \mathrm{~h}$, intra- (A) and extracellular (B) MUC5AC protein levels in NCI-H292 cells were measured using dot blot hybridization. Data are expressed as the mean \pm standard deviation $(n=6)$. The significance of differences was analyzed using a one-way ANOVA with Dunnett's multiple comparison test. ${ }^{* *} \mathrm{p}<0.01 v$ s the LPS group

In the present study, we showed the suppressive effects of Welsh onion on mucin synthesis in LPS-treated NCI-H292 cells, and the results obtained suggest that Welsh onion has the potential to improve mucus hyper-production in airways. We will attempt to identify the active compounds of Welsh onion in our future research. Furthermore, since data for Welsh onion are limited to in vitro experiments, we intend to perform experimental animal studies and clinical tests on humans.

Conflict of interest: We declare that we have no conflict of interest.

\section{References}

1. Ueda, H., Takeuchi, A., Wako, T. Activation of immune responses in mice by an oral administration of bunching onion (Allium fistulosum) mucus. (2013) Biosci Biotechnol Biochem 77(9): 1809-1813.

2. Ramkissoon, J. S., Mahomoodally, M. F., Ahmed, N., et al. Antioxidant and anti-glycation activities correlates with phenolic composition of tropical medicinal herbs. (2013) Asian Pac J Trop Med 6(7): 561569.

3. Arulselvan, P., Wen, C.C., Lan, C.W., et al. Dietary administration of scallion extract effectively inhibits colorectal tumor growth: cellular and molecular mechanisms in mice. (2012) PLoS One 7(9): e44658.

4. Lee, J.B., Miyake, S., Umetsu, R., et al. Anti-influenza A virus effects of fructan from Welsh onion (Allium fistulosum L.). (2012) Food Chem 134(4): 2164-2168.

5. Rose, M.C., Nickola, T.J., Voynow, J.A. Airway mucus obstruction: Mucin glycoproteins, MUC gene regulation and goblet cell hyperplasia. (2001) Am J Respir Cell Mol Biol 25(5): 533-537.

6. Thai, P., Loukoianov, A., Wachi, S. et al. Regulation of airway mucin gene expression. (2008) Annu Rev Physiol 70: 405-429.

7. Voynow, J.A., Rubin B.K. Mucins, mucus, and sputum. (2009) Chest 135(2): 505-512.

8. Takeyama, K., Dabbagh, K., Lee H.M., et al. Epidermal growth factor system regulates mucin production in airways. (1999) Proc Natl Acad Sci USA 96(6): 3081-3086.

9. Takeyama, K., Jung, B., Shim J.J., et al. Activation of epidermal growth factor receptors is responsible for mucin synthesis induced by cigarette smoke. (2001) Am J Physiol Lung Cell Mol Physiol 280(1): L165-L172.

10. Wang Y., Shen Y., Li K., et al. Role of matrix metalloproteinase-9 in lipopolysaccharide-induced mucin production in human airway epithelial cells. (2009) Arch Biochem Biophys 486(2): 111-118.

11. Yasuo, M., Fujimoto, K., Imamura, H., et al. L-carbocisteine reduces neutrophil elastase-induced mucin production. (2009) Respir Physiol Neurobiol 167(2): 214-216.

12. Shimizu, T., Shimizu, S. Azithromycin inhibits mucus hypersecretion from airway epithelial cells. (2012) Mediators Inflamm 2012: 265714.

13. Iwashita, J., Yamamoto, T., Sasaki, Y., et al. MUC5AC production is down regulated in NCI-H292 lung cancer cells cultured on type-IV collagen. (2010) Mol Cell Biochem 337(1-2): 65-75.

14. Itoh, M., Abe, Y., Iwama, Y., et al. HPLC analysis of lipoproteins in culture medium of hepatoma cells: an in vitro system for screening anti hyper lipidemic drugs. (2009) Biotechnol Lett 31(7): 953-957.

15. Perrais, M., Pigny, P., Copin, M.C., et al. Induction of MUC2 and MUC5AC mucins by factors of the epidermal growth factor (EGF) family is mediated by EGF receptor/Ras/Raf/extracellular signal-regulated kinase cascade and Sp1. (2002) J Biol Chem 277(35): 32258-32267. 